Jurnal Pengendalian Pencemaran Lingkungan (JPPL)

Vol.1 No.01 September 2019

\title{
STUDI STABILITAS SISTEM SUB SURFACE FLOW CONSTRUCTED WETLAND (SSF-CW) MENGGUNAKAN TANAMAN MELATI AIR DAN MEDIA TANAM ZEOLIT UNTUK MENURUNKAN LOGAM Hg
}

\author{
Study of Sub Constructed Wetland (SSF-CW) System Using Echinodorus
} Palaefolius Plant and Zeolit Plant Media in Reducing Hg Metals

\author{
Angge Dhevi Warisaura ${ }^{1}$, Ilma Fadlilah $^{2}$, Agus Prasetya ${ }^{3}$, Moh. Fahrurrozi ${ }^{3}$ \\ ${ }^{1}$ Jurusan Teknik Lingkungan, Institut Sains dan Teknologi AKPRIND, Yogyakarta, Indonesia \\ ${ }^{2}$ Jurusan Teknik Rekayasa Pengendalian Pencemaran Lingkungan, Politeknik Negeri Cilacap, Indonesia \\ ${ }^{3}$ Departemen Teknik Kimia, Fakultas Teknik, Universitas Gadjah Mada, Indonesia
}

"Penulis korespondensi. No Tel: 085743137413. Email: angge@akprind.ac.id

\begin{abstract}
Abstrak
Penambangan emas rakyat pada umumnya menggunakan merkuri $(\mathrm{Hg})$ yang sering disebut dengan proses amalgamasi. Pemakaian merkuri ini mengakibatkan penurunan kualitas lingkungan terutama akibat pelepasan $\mathrm{Hg}$ tersebut ke perairan. Pada penelitian ini dilakukan penurunan kadar merkuri pada air limbah tambang emas rakyat dengan memanfaatkan teknologi menggunakan sistem Sub Surface Flow - Constructed Wetland (SSFCW). Tujuan penelitian ini adalah untuk menentukan stabilitas Sub Surface Flow Constructed Wetlands dalam menurunkan kadar $\mathrm{Hg}$ dalam air dengan kombinasi metode fitoremediasi menggunakan tanaman melati air (Echinodorus Palaefolius) dan media tanam zeolit. Model sistem SSF-CW ini mempunyai dimensi $820 \mathrm{~mm} x$ $320 \mathrm{~mm}$ x $585 \mathrm{~mm}$ terdiri dari 3 zona, yaitu zona inlet, zona reaksi dan zona outlet. Penelitian dilakukan dengan konsentrasi limbah $\mathrm{HgCl}_{2}$ awal sebesar $14,94 \mathrm{mg} / \mathrm{L}$ yang dilakukan dengan dua tahap yakni kontinyu dan batch selama 12 jam dan berlangsung selama 3 hari untuk setiap tahapnya. Sampel effluent yang diambil setiap 0 jam, 4 jam, 8 jam, 12 jam setiap harinya untuk dianalisis kadar merkurinya menggunakan Direct Mercury Analyzer (DMA). Hasil penelitian menunjukkan bahwa stabilitas sistem SSF-CW yang mengkombinasikan antara media tanam berupa zeolit dan tanaman melati air terlihat cukup baik untuk mendukung proses penurunan kadar logam Hg dalam air limbah dengan efisiensi penurunan sebesar 98,99\%. Hal ini dibuktikan dari tanaman melati air dapat beradaptasi dengan baik pada sistem yang dibuat dan mempunyai kemampuan akumulasi logam dengan nilai BCF sebesar 9,117. Adapun berdasarkan kemampuan media tanam, zeolit masih jauh dari kapasitas jenuhnya untuk menjerap merkuri.
\end{abstract}

Kata kunci: Hg, Melati Air, Sub Surface Flow Constructed Wetlands, Zeolit.

\begin{abstract}
Amalgamation to gold in artisanal small scale generally uses mercury (Hg) that decrease the quality of environment especially water. A study of mercury artisanal small scale gold mine waste water was conducted by utilizing simple technology using Sub Surface Flow - Constructed Wetland (SSF-CW) system. This system is a combination of phytoremediation methods using Echinodorus palaefolius plant with zeolite as growth media. The purpose of this study was to determine the stability of $\mathrm{SSF}-\mathrm{CW}$ in reducing $\mathrm{Hg}$ concentration in water. This SSF-CW system model has dimensions of $820 \mathrm{~mm} \times 320 \mathrm{~mm} \times 585 \mathrm{~mm}$ consisting of 3 zones, namely the inlet zone, the reaction zone and the outlet zone. The study was conducted with an initial $\mathrm{HgCl}_{2}$ waste concentration of $14.94 \mathrm{mg} / \mathrm{L}$ which was carried out in two stages, continuous and batch for 12 hours and lasted for 3 days for each stage. Effluent samples were taken every 0 hours, 4 hours, 8 hours, and 12 hours
\end{abstract}


Jurnal Pengendalian Pencemaran Lingkungan (JPPL)

Vol.1 No.01 September 2019

for mercury concentration analysis using Direct Mercury Analyzer (DMA). The result showed that SSF-CW could support the process of reducing Hg concentration $n$ wastewater with removal efficiency of $98.99 \%$. Echinodorus had the ability to accumulate metals with a BCF value of 9,117 and the accumulation of $\mathrm{Hg}$ in the zeolite (as growth media) was still far from the saturated capacity to absorb mercury.

Keywords: Hg, Echinodorus palaefolius, Sub Surface Flow Constructed Wetland, Zeolite.

\section{PENDAHULUAN}

Pencemaran air oleh logam berat menjadi salah satu hal yang penting untuk ditangani saat ini. Merkuri (Hg) merupakan salah satu logam berat yang sangat beracun. Merkuri mampu beredar dalam jangkauan luas, sulit terurai dan dapat terbioakumulasi sehingga logam berat ini menjadi masalah global (UNEP, 2002). Di Indonesia, $\mathrm{Hg}$ digunakan untuk ekstraksi bijih emas dalam proses amalgamasi oleh para penambang emas skala kecil atau penambang emas rakyat. Indonesia menjadi penyumbang cemaran $\mathrm{Hg}$ pada air dan tanah terbesar ketiga di dunia, karena memiliki potensi penghasil batuan emas yang tinggi (UNEP, 2002). Sejumlah kasus pencemaran merkuri yang dihasilkan dari proses penambangan emas di Indonesia telah terindikasi menyebabkan pencemaran lingkungan.

Teknologi yang telah dikembangkan dalam pengolahan kontaminan logam berat khususnya merkuri dalam air antara lain presipitasi kimia, adsorpsi, filtrasi membran, dan bioremediasi. Adsorpsi telah digunakan untuk menghilangkan merkuri anorganik dari air tanah dan air limbah. Adsorben yang dikenal memiliki nilai jual murah dan mudah didapat adalah zeolit. Zeolit merupakan senyawa alumino silikat yang memiliki bentuk kristal sangat teratur dengan rongga saling berhubungan sehingga menyebabkan luas permukaan zeolit sangat besar dan sangat baik digunakan sebagai adsorben. Namun di sisi lain, penggunan zeolit dalam menurunkan kandungan merkuri dalam air tidak cukup efektif dikarenakan setiap adsorben memiliki kapasitas penjerapan tertentu. Oleh karena itu, adsorpsi dengan zeolit perlu dikombinasikan dengan metode lain yang bisa melengkapi kelemahan adsorben zeolit dalam upaya menjerap merkuri. Dalam metode pengolahan secara biologis, metode fitoremediasi dipilih karena pengolahan limbah dengan menggunakan tanaman dapat digunakan untuk removal, transfer, menstabilkan, atau menghancurkan kontaminan dalam tanah, sedimen, dan air (US EPA, 2007). Fitoremediasi didefinisikan juga sebagai penyerap polutan yang dimediasi oleh tumbuhan termasuk pohon, rumput-rumputan, dan tumbuhan air. Pencucian bisa berarti penghancuran, inaktivasi atau imobilisasi polutan ke bentuk yang tidak berbahaya (Chaney dkk., 1995).Proses fitoremediasi ini biasa dilakukan dalam sebuah sistem pengolahan air limbah bernama Constructed Wetland (CW). Constructed Wetland atau Sistem Lahan Basah Buatan merupakan proses pengolahan limbah yang meniru/aplikasi dari proses penjernihan air yang terjadi dilahan basah/rawa (Wetland), dimana tumbuhan air (Hydrophita) yang tumbuh didaerah tersebut memegang peranan penting dalam proses pemulihan kualitas air limbah secara alamiah (self purification). Definisi tersebut disempurnakan oleh Metcalf \& Eddy (1993), menjadi Sistem yang termasuk pengolahan alami, dimana terjadi aktivitas pengolahan sedimentasi, filtrasi, transfer gas, adsorpsi, pengolahan kimiawi dan biologis, karena aktivitas mikroorganisme dalam tanah dan aktivitas tanaman. Di negara tropis seperti Indonesia, tipe aliran horizontal lebih sering diaplikasikan secara 
Jurnal Pengendalian Pencemaran Lingkungan (JPPL)

Vol.1 No.01 September 2019

kontinu dalam Sub Surface Flow Constructed Wetlands karena operasional yang mudah dan biaya perawatan yang rendah (Sarafraz dkk., 2009). Sub Surface Flow air tidak menggenang di atas media tanam, tetapi air mengalir di bawah media tanam sehingga tanaman yang sesuai adalah jenis tanaman air emergent, yaitu setengah tenggelam dalam air. Sehingga tanaman emergent yang dipilih sebagai penyerap logam berat adalah melati air (Echinodorus palaefolius).

Sebelumnya, penggunaan media berupa zeolit dalam penjerapan logam berat telah diteliti. Mudasir dkk (2016) melakukan penelitian penjerapan ion Hg (II) dengan zeolit teraktivasi. Hasil percobaan menunjukkan bahwa kapasitas adsorpsi zeolit teraktivasi adalah $8 \mu \mathrm{mol} /$ gram. Persamaan kesetimbangan adsorpsi yang paling cocok untuk menentukan kapasitas maksimum adsorpsi zeolit adalah Isoterm Langmuir. Dalam penelitian lain, Malik dkk (2016) melakukan analisis potensi tanaman air sebagai fitoremediator logam kromium dalam limbah cair tekstil. Adapun tanaman fitoakumulator yang diteliti adalah Zantedeschia aethiopica (kala lili), Pontederia lanceolata (lavender air) dan Echinodorus palaefolius (melati air). Hasil penelitian menunjukkan bahwa tanaman Echinodorus palaefolius memiliki potensi paling tinggi dalam akumulasi logam kromium dari limbah cair tekstil yakni mampu mengakumulasi logam kromium sebesar 6,12 ppm dan mampu menurunkan konsentrasi kromium dalam limbah cair tekstil dari 1,21 mg/L menjadi 0,03 mg/L. Tujuan penelitian ini adalah untuk menentukan stabilitas Sub Surface Flow Constructed Wetlands dalam menurunkan kadar Hg dalam air dengan kombinasi metode fitoremediasi menggunakan tanaman melati air dan adsorpsi zeolit.

\section{METODE PENELITIAN}

\subsection{Alat dan Bahan Penelitian}

Bahan penelitian yang digunakan adalah air limbah merkuri artifisial yang dibuat dari reagen $\mathrm{HgCl}_{2}$ p.a Emsure (Merck), tanaman melati air (Echinodorus palaefolius) dengan ukuran seragam, segar, bebas hama, tanpa kehilangan akar maupun bunganya (toko tanaman "Studio 4" Gembiraloka), zeolit alam (Klaten, Jawa Tengah) dan aquades. Sedangkan alat penelitian utama yang digunakan dalam penelitian ini adalah sebuah reaktor yang terdiri dari sebuah bak berbahan akrilik tebal $1 \mathrm{~mm}$ dengan sekat berlubang, pipa PVC, pompa, dan kran. Adapun ukuran reaktor adalah $82 \mathrm{~cm}$ x $32 \mathrm{~cm}$ x 58,5 cm. Sampling untuk pengukuran kadar $\mathrm{Hg}$ dapat dilakukan dari bak tampungan pipa outlet. Gambar rangkaian alat dapat dilihat pada Gambar 1 berikut: 
Jurnal Pengendalian Pencemaran Lingkungan (JPPL)

Vol.1 No.01 September 2019

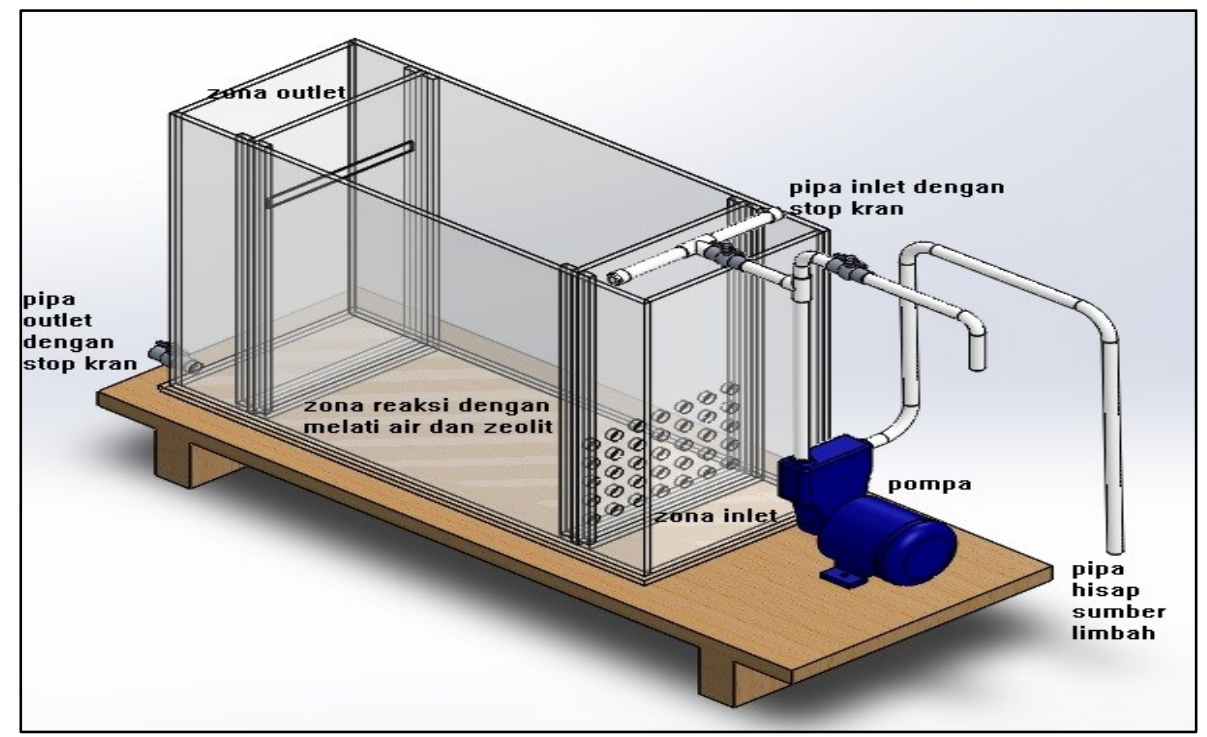

Gambar 1. Sub Surface Flow Constructed Wetland Tampak Keseluruhan

\subsection{Prosedur Penelitian.}

Tahapan penelitian diawali dengan aklimatisasi tanaman melati air yang ditanamkan dalam media zeolit setinggi $45 \mathrm{~cm}$ pada zona reaksi selama 30 hari sehingga dapat menyesuaikan diri dari lingkungan baru dan dapat bertahan hidup. Selanjutnya adalah proses removal $\mathrm{Hg}$ dari air limbah $\mathrm{HgCl}_{2}$ artifisial dengan konsentrasi 14,94 mg/L yang dilakukan dalam 2 tahap. Pada operasi tahap I dijalankan 72 jam, dengan setiap harinya beroperasi dalam 2 mode :

1. Kontinyu selama 12 jam dari jam 08.00-20.00 dengan flowrate 7,62 L/jam, sampling dilakukan pada jam ke $0 ; 4 ; 8$ dan 12 .

2. Batch selama 12 jam dari jam 20.00-08.00. Pada saat batch, air limbah $\mathrm{HgCl}_{2}$ berhenti dialirkan

. Sampel effluent yang diambil setiap 0 jam, 4 jam, 8 jam, 12 jam setiap harinya untuk dianalisis kadar merkurinya menggunakan DMA (Direct Mercury Analyzer). Semua effluen dari tahap I sampai hari ketiga ditampung untuk dialirkan kembali ke dalam sistem SSF-CW sebagai operasi tahap II. Operasi tahap II dimulai 27 hari setelah pemberhentian proses dan dimulai lagi dengan mode yang sama seperti tahap I selama 72 jam.

\subsection{Penentuan Bio Concentration Factor (BCF) dan Translocation Factor (TF)}

Untuk menentukan tanaman melati air mampu menjerap dan mendistribusikan ion logam $\mathrm{Hg}$ dapat dilihat dari nilai BCF dan TF melati air. Nilai BCF menunjukkan perbandingan konsentrasi logam yang terdapat dalam jaringan tanaman dengan konsentrasi logam yang terdapat dalam media, sedangkan nilai TF menunjukkan potensi mobilitas logam dari akar ke batang dan dari akar ke daun Nilai BCF dihitung dengan persamaan berikut :

$\mathrm{BCF}=\frac{C_{B}}{C_{S}}$

dengan :

$\mathrm{C}_{\mathrm{B}}$ adalah : konsentrasi total logam pada tanaman $(\mathrm{mg} / \mathrm{g})$, danC $\mathrm{C}_{\mathrm{S}}$ adalah : konsentrasi logam dalam tanah atau media $(\mathrm{mg} / \mathrm{g})$. 
Jurnal Pengendalian Pencemaran Lingkungan (JPPL)

Vol.1 No.01 September 2019

Apabila BCF sama dengan atau lebih dari 1, : maka tanaman yang diuji termasuk tanaman akumulator, yaitu tanaman yang sanggup mengakumulasi logam.

Nilai TF dihitung dengan persamaan:

$\mathrm{TF}=\frac{C_{s}}{C_{r}}$ atau $\mathrm{TF}=\frac{C_{l}}{C_{r}}$

Dengan $\mathrm{Cs}_{\text {: }}$ adalah konsentrasi logam pada batang $(\mathrm{mg} / \mathrm{g}), \mathrm{C}_{1}$ : adalah konsentrasi logam pada daun (mg/g), dan $\mathrm{Cr}$ : adalah konsentrasi logam pada akar (mg/g).

Apabila nilai TF sama dengan atau lebih dari 1, maka mobilitas logam dari suatu bagian tanaman ke bagian tanaman lain pada tanaman tersebut adalah baik.

\section{HASIL DAN PEMBAHASAN}

\subsection{Penurunan Kadar Logam Hg pada Effluen}

Kadar merkuri menjadi parameter penting dalam sistem SSF-CW yang telah dirancang. Hal ini dikarenakan sebagai ukuran keefektifan sistem dalam pengurangan ( ) merkuri pada air limbah. Dalam proses ini digunakan air limbah sintetik Hg dengan konsentrasi Hg sebesar 14,94 mg/L pada tahap I. Semua effluen dari tahap 1 ditampung untuk dialirkan kembali ke dalam sistem SSF-CW sebagai operasi tahap II dengan kadar merkuri influen sebesar 1,17 mg/L. Dari hasil percobaan, diketahui adanya penurunan kadar logam $\mathrm{Hg}$ yang signifikan seperti terlihat pada Gambar 2. Adapun grafik ditampilkan secara bersambung dari mode kontinyu pada tahap I hingga tahap II dengan total waktu paparan kontinyu 72 jam.

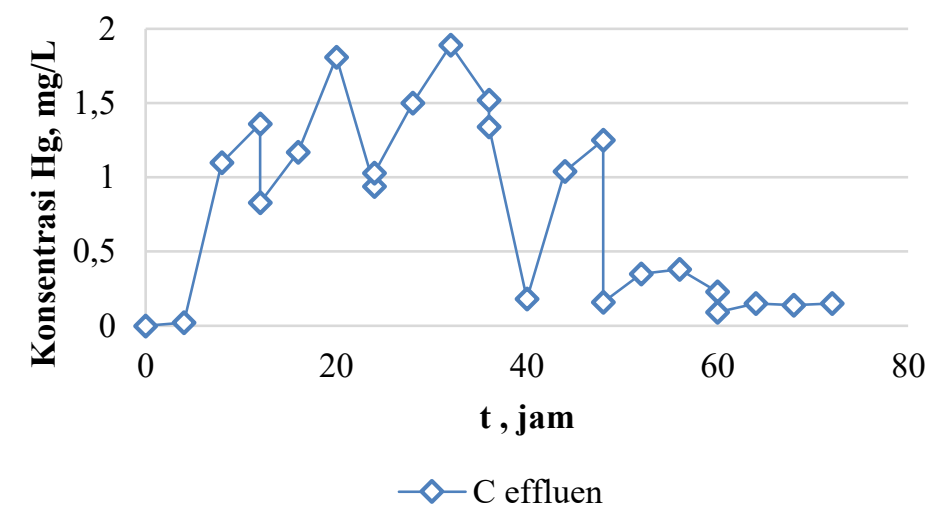

Gambar 2. Konsentrasi merkuri di cairan terhadap waktu operasi

Dari grafik terlihat bahwa terjadi fluktuasi kadar merkuri yang keluar dari sistem SSF-CW. Pada 36 jam pertama (tahap I), kadar effluen terendah tercapai pada keluaran pertama waktu tinggal yaitu di jam ke-4, dengan kadar 0,002 mg/L. Setelah itu setiap tahapan waktu tinggal, kadar merkuri mengalami naik dan turun antara $0,8 \mathrm{mg} / \mathrm{L}$ hingga $1,89 \mathrm{mg} / \mathrm{L}$. Sedangkan pada 36 jam selanjutnya (tahap II), dengan kadar influen air limbah rata-rata $1,17 \mathrm{mg} / \mathrm{L}$, kadar effluen memiliki range kadar $0,09 \mathrm{mg} / \mathrm{L}$ hingga $0,38 \mathrm{mg} / \mathrm{L}$, untuk kadar effluen pada jam ke 44-48 terjadi lonjakan konsentrasi di luar batas normal karena melebihi kadar influen, kemudian berangsur turun pada jam-jam selanjutnya. Lonjakan konsetrasi Hg pada tahap II dikarenakan dimungkinkan terjadi desorpsi atau sebagian $\mathrm{Hg}$ terjerap ash out ke zona effluen. 
Jurnal Pengendalian Pencemaran Lingkungan (JPPL)

Vol.1 No.01 September 2019

\subsection{Stabilitas Sistem SSF-CW}

Dalam sistem ini, dua komponen utama yaitu tanaman melati air dan zeolit memegang peranan penting. Tingkat kejenuhan zeolit perlu diketahui sebagai dasar langkah menentukan penggantian media. Komponen tanaman fitoremediator tidak kalah penting, selain kemampuan menjerap logam, kondisi fisik dan pertumbuhan tanaman harus tetap hidup hingga akhir penelitian, artinya tetap bertumbuh dalam kondisi air mengandung logam berat.

\subsubsection{Efek Paparan Logam Hg Terhadap Tanaman Melati Air}

Melihat keseluruhan perkembangan tanaman melati air pada operasi kontinyu tahap I, terlihat respon morfologis pada tanaman yaitu adanya klorosis, yaitu daun mulai menguning karena kegagalan pembentukan klorofil diikuti dengan nekrosis, yaitu kematian pada daun ditandai dengan layu dan mengering. Setelah terjadi nekrosis pada helaian daun, kemudian daun tersebut berubah warna menjadi coklat dan layu.
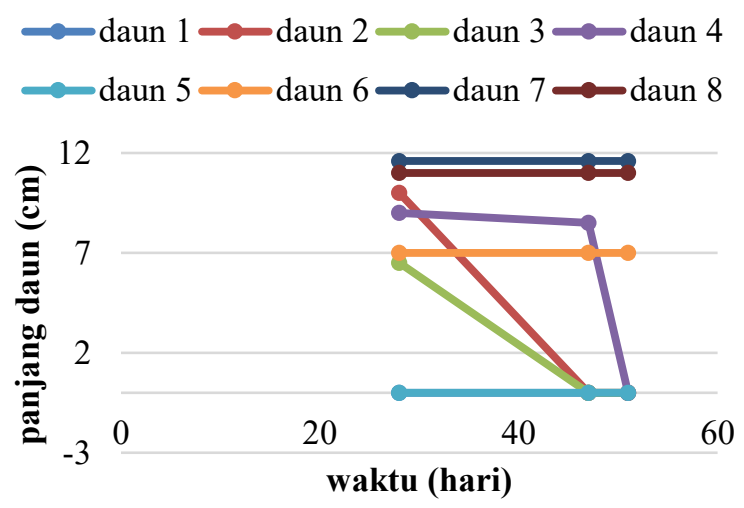

(a)

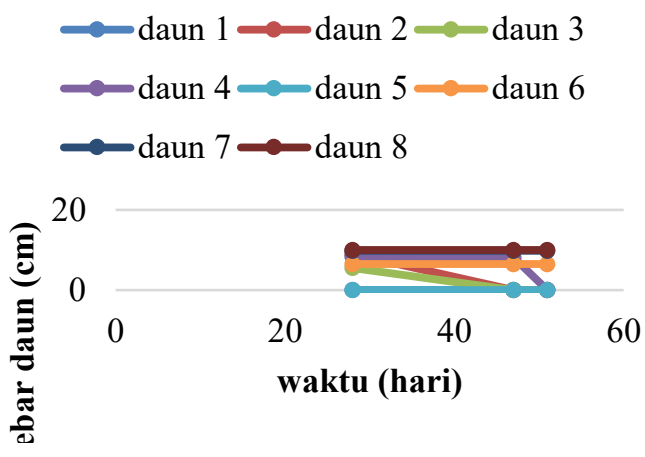

(b)

Gambar 3. Perkembangan tanaman melati air 1 pada tahap I adsorpsi-fitoremediasi (a) panjang daun dan (b) lebar daun.

Pada tanaman 1, pada kondisi awal setelah pemrosesan tahap I menggunakan limbah mengandung $\mathrm{Hg}$ kondisi batangnya hijau, 4 daun pinggir kecoklatan, 2 daun tumbuh segar, daun nomor 5 mati. Kemudian pada hari ke-47, 2 daun menyusul mati, dan hari ke-51 satu daun lagi menyusul mati.
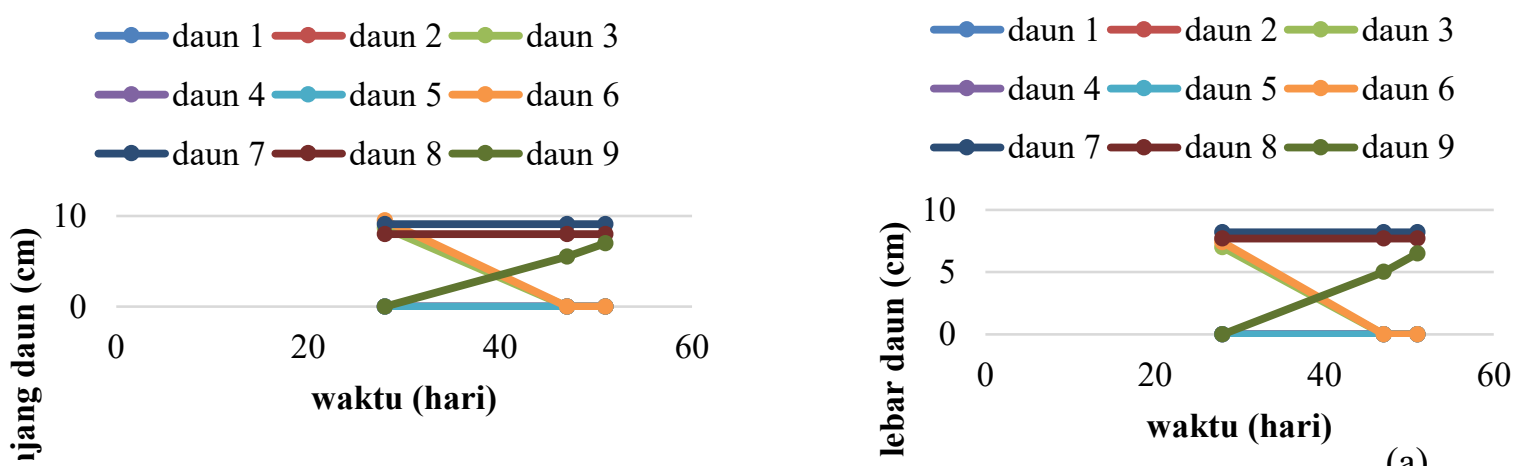

(a)

Gambar 4. Perkembangan tanaman melati air 2 pada tahap I adsorpsi-fitoremediasi (a) panjang daun, dan

(b) lebar daun. 
Jurnal Pengendalian Pencemaran Lingkungan (JPPL)

Vol.1 No.01 September 2019

Pada tanaman 2, pada kondisi awal setelah pemrosesan tahap 1 menggunakan limbah mengandung $\mathrm{Hg}$ kondisi batang agak coklat, 2 daun pinggir kecoklatan, 2 daun segar, daun nomor 2 serta 5 mati. Kemudian pada hari ke-47, 2 daun menyusul mati tetapi tumbuh 1 lagi yaitu daun ke-9, dan hari ke-51 daun ke-9 semakin tumbuh dengan normal.

Setelah satu bulan tidak ada aliran limbah mengandung merkuri yang masuk, operasi kembali berjalan secara kontinyu dengan konsentrasi lebih rendah, yaitu sesuai konsentrasi keluaran pada tahap I. Pada operasi tahap II ini, tanaman melati air, awalnya hanya mempunyai 3 hingga 4 helai daun per tanaman. Setelah proses tahap II bertambah menjadi 5 hingga 6 helai daun per tanaman.

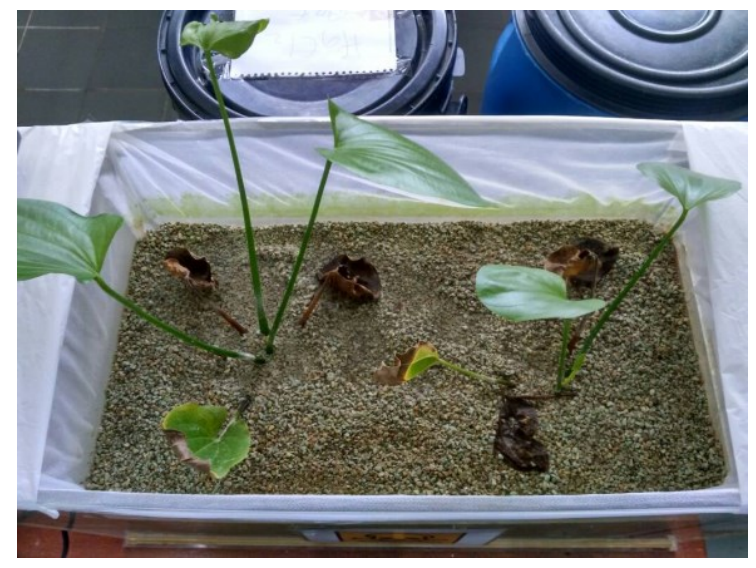

(a)

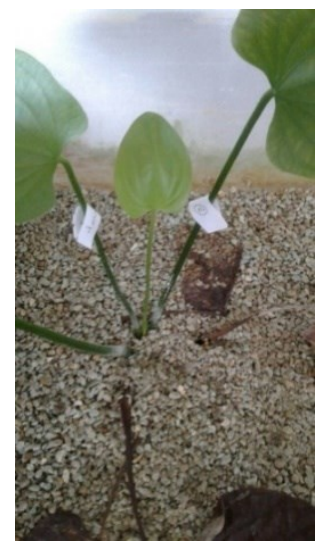

(b)

Gambar 5. Efek paparan $\mathrm{Hg}$ terhadap tanaman melati air (a) klorosis dan nekrosis pada daun dan (b) tunas baru yang tumbuh.

Meskipun terjadi juga klorosis dan nekrosis pada tanaman hingga beberapa helaian daun mengalami kematian, namun tanaman melati air tetap sanggup beradaptasi bahkan tumbuh tunas baru pada tahap ini.

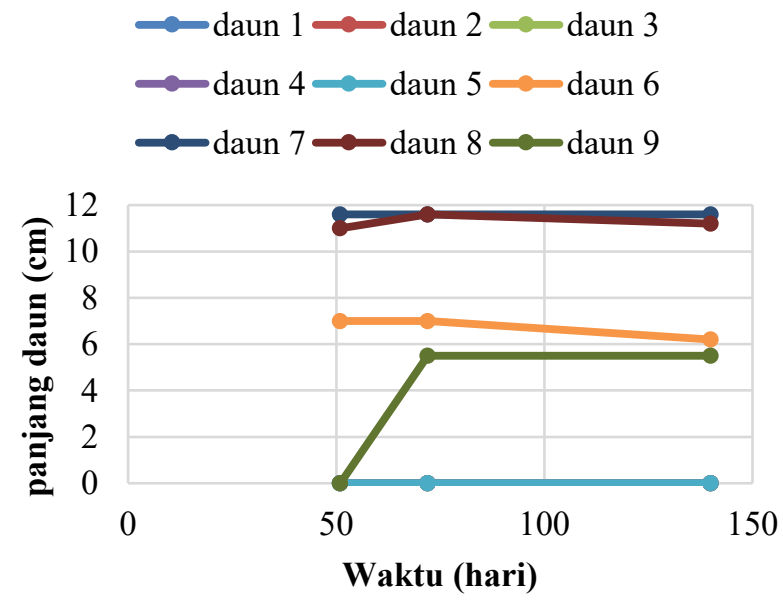

(a)

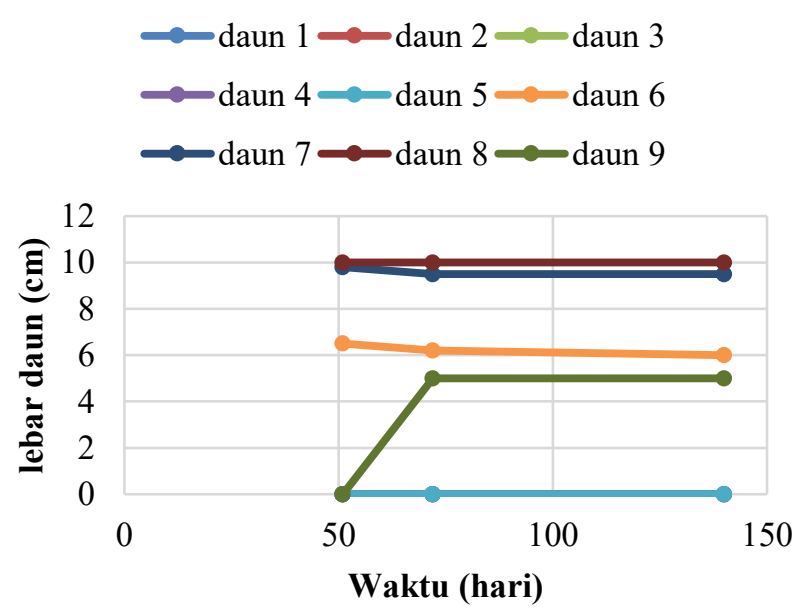

(b)

Gambar 6. Perkembangan tanaman melati air 1 pada tahap II adsorpsi-fitoremediasi (a) panjang daun, dan (b) lebar daun. 
Jurnal Pengendalian Pencemaran Lingkungan (JPPL)

Vol.1 No.01 September 2019

Pada tanaman 1, pada kondisi awal setelah pemrosesan tahap 2 menggunakan limbah mengandung $\mathrm{Hg}$ kondisi daunnya mati 1 yaitu nomor 4 . Kemudian pada hari ke-72 tumbuh daun baru dan bertumbuh hingga hari terakhir pengukuran.

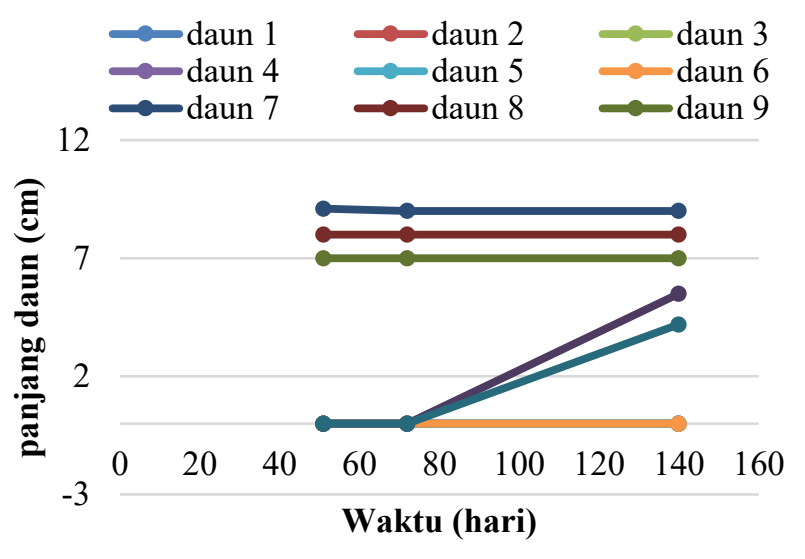

(a)

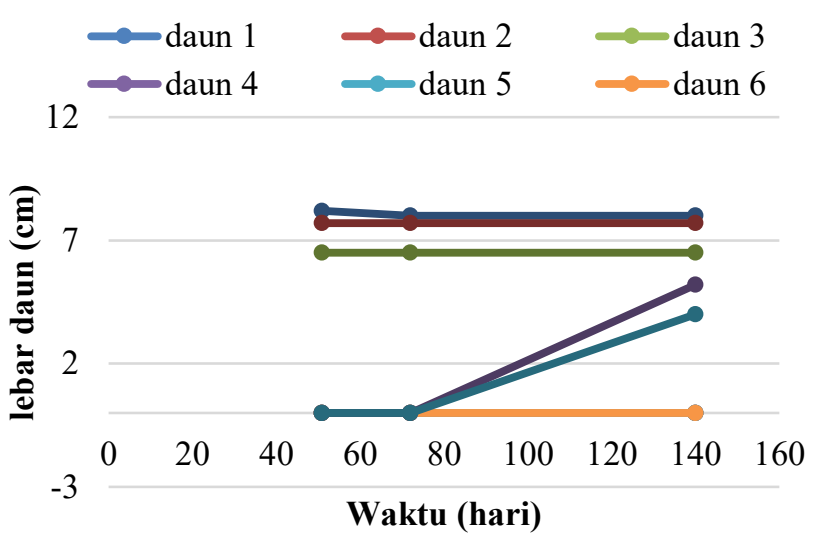

(b)

Gambar 7. Perkembangan tanaman melati air 2 pada tahap II adsorpsi-fitoremediasi (a) panjang daun, dan

(b) lebar daun.

Pada tanaman 2, pada kondisi awal setelah pemrosesan tahap 2 menggunakan limbah mengandung $\mathrm{Hg}$ kondisinya tumbuh daun baru yaitu nomor 9 dan bertumbuh hingga hari ke-72. Pada hari terakhir pengukuran., tanaman ini bertunas sehingga terukur 2 daun baru yaitu nomor 10 dan 11.

\subsubsection{Akumulasi Logam Hg Pada Tanaman Melati Air}

Untuk mengetahui seberapa besar merkuri yang terjerap pada tanaman selama pengoperasian SSF$\mathrm{CW}$, dilakukan analisis kadar Hg di setiap bagian tanaman. Dari berat basah tanaman ditimbang sebelum dan setelah pengoperasian SSF-CW, kemudian diambil secukupnya sampel tanaman, baik akar, batang maupun daun. Massa tanaman per bagian akar, daun dan batang sebelum operasi tidak dihitung karena keterbatasan sampel uji tanaman. Prosentase berat setiap bagian tanaman terlihat pada Tabel 1 berikut :

Tabel 1. Prosentase fraksi massa tanaman melati air

\begin{tabular}{|l|c|c|c|}
\hline $\begin{array}{l}\text { Bagian } \\
\text { tanaman }\end{array}$ & $\begin{array}{c}\text { Massa } \\
\text { tanaman rata-rata } \\
\text { sebelum operasi, }\end{array}$ & $\begin{array}{c}\text { Massa } \\
\text { tanaman rata-rata } \\
\text { setelah operasi, g }\end{array}$ & $\begin{array}{c}\text { Fraksi } \\
\text { massa } \\
\text { tanaman, \% }\end{array}$ \\
\hline Akar & - & 8,65 & 36,73 \\
\hline Batang & - & 10,53 & 44,72 \\
\hline Daun & - & 4,37 & 18,55 \\
\hline Total & 80,65 & 23,55 & 100 \\
\hline
\end{tabular}

Data massa tanaman tersebut dalam rata-rata sehingga jika dalam sistem mempunyai 2 tanaman maka total massa tanaman sebelum operasi adalah 161,3 gram. dan setelah operasi menjadi 47,1 gram. Dari data tersebut terlihat bahwa tanaman sebelum dan sesudah pengoperasian SSF-CW mengalami penurunan massa 
Jurnal Pengendalian Pencemaran Lingkungan (JPPL)

Vol.1 No.01 September 2019

sebesar 70\%. Penurunan berat basah tanaman ini merupakan efek dari toksisitas $\mathrm{Hg}$ terhadap tanaman sehingga pertumbuhan tanaman mengalami hambatan meski tetap bertahan hidup. Dari setiap bagian tanaman tersebut akan dianalisis sebaran konsentrasi Hg di setiap bagian tanaman, akumulasi pada tanaman terlihat pada Tabel 2.

Tabel 2. Perhitungan Hg terjerap di setiap bagian tanaman

\begin{tabular}{|c|r|c|c|c|c|c|l|}
\hline \multirow{2}{*}{$\begin{array}{c}\text { Bagian } \\
\text { tanaman } \\
\text { melati air }\end{array}$} & \multicolumn{2}{|c|}{$\begin{array}{c}\text { Sebelum } \\
\text { pengoperasian SSF-CW }\end{array}$} & \multicolumn{2}{c|}{$\begin{array}{c}\text { Setelah } \\
\text { pengoperasian SSF- }\end{array}$} & \multicolumn{2}{|c|}{ Hg terjerap di tanaman } & $\begin{array}{c}\text { Hg } \\
\text { akumulatif di } \\
\text { bagian }\end{array}$ \\
\cline { 2 - 7 } & $\mathbf{( m g / k g )}$ & $\mathbf{( m g / g )}$ & $\mathbf{( m g / k g )}$ & $\mathbf{( m g / g )}$ & $\mathbf{( m g / k g )}$ & $\mathbf{( m g / g )}$ & tanaman, $\mathbf{m g}$ \\
\hline Akar & 1,695 & 0,001695 & 37,53 & 0,03753 & 35,835 & 0,035835 & 0,30997275 \\
\hline Batang & 0,149 & 0,000149 & 10,23 & 0,01023 & 10,081 & 0,010081 & 0,10615293 \\
\hline Daun & 1,907 & 0,001907 & 3,26 & 0,00326 & 1,353 & 0,001353 & 0,00591261 \\
\hline
\end{tabular}

Dari data tersebut dapat dihitung akumulasi Hg di tanaman dengan menjumlahkan Hg terakumulasi di semua bagian tanaman yaitu sebesar 0,42203829 mg. Akumulasi $\mathrm{Hg}$ tersebut dalam setiap tanaman dengan berat rata-rata 24,63 gram. Maka dari itu rata-rata akumulatif $\mathrm{Hg}$ di tanaman sebesar 0,017135132 mg/g. Adapun konsetrasi Hg pada tanaman terbanyak pada bagian akar. Hal ini sesuai dengan mekanisme kerja tanaman, dimana akar merupakan pintu masuk metabolisme unsur hara dari dalam tanah.

Tanaman melati air memang terbukti mampu menjerap logam berat, terutama $\mathrm{Hg}$, hal ini terlihat dari hasil perhitungan akumulasi Hg pada setiap bagian tanaman. Bukti lain tanaman melati air mampu menjerap dan mendistribusikan ion logam Hg dapat melihat nilai BCF dan TF melati air yang didapat melalui persamaan (1) dan (2). Nilai BCF yang didapatkan adalah sebesar 9,117. Dengan nilai BCF lebih dari 1 ini mengindikasikan bahwa tanaman melati air merupakan tanaman akumulator, yakni sanggup mengakumulasi logam. Sedangkan nilai TF yang didapatkan dari TF akar ke batang dan TF akar ke daun berturut-turut adalah sebesar 0,281 dan 0,037. Nilai TF yang kurang dari 1 ini mengindikasikan bahwa translokasi logam Hg pada tanaman ini kurang baik, meski tetap ada kadar $\mathrm{Hg}$ di setiap bagian tanaman.

Terlihat dari hasil perhitungan BCF dan TF dapat disimpulkan bahwa terdapat akumulasi logam cukup besar pada akar, untuk kemudian pada batang daun sejumlah kecil saja kadar Hg. Menurut Malik (2016), tanaman memiliki mekanisme tersendiri untuk menstimulasi bioavailabilitas ion-ion logam pada rhizosfer agar diserap melalui akar. Logam masuk ke dalam akar tanaman melalui apoplas korteks akar secara transpor pasif kemudian ditransportasikan menuju batang dan daun. Dalam apoplas juga banyak mengandung senyawa muatan negatif yang berperan sebagai kompleks pengikat kation dan pelepas anion. Hal ini membuktikan bahwa kinerja transpor pasif memalui apoplas kurang begitu baik.

\subsubsection{Akumulasi Logam Hg Pada Zeolit}

Berdasarkan perhitungan neraca massa dalam sistem, merkuri terakumulasi di akhir proses sebesar $0,080 \mathrm{mg} / \mathrm{g}$. Adapun kemampuan zeolit dalam menjerap merkuri pada uji isotherm adsorpsi menghasilkan nilai kapasitas maksimum adsorpsi sebesar $0,727 \mathrm{mg} / \mathrm{g}$ adsorben zeolit (Utami, 2017). Kedua data penting 
Jurnal Pengendalian Pencemaran Lingkungan (JPPL)

Vol.1 No.01 September 2019

tersebut diplot ke dalam grafik sehingga terlihat $\mathrm{Hg}$ yang terakumulasi dalam sistem SSF-CW masih berada jauh di bawah kapasitas adsorbsi maksimumnya. Zeolit alam yang digunakan dalam penelitian ini mampu maksimalnya $0,727 \mathrm{mg}$ ion merkuri per gram adsorben, sedangkan pada 72 jam paparan masih berada pada posisi $0,080 \mathrm{mg}$ per gram adsorben, sekitar $11 \%$ saja dari kapasitas adsorpsi maksimumnya.

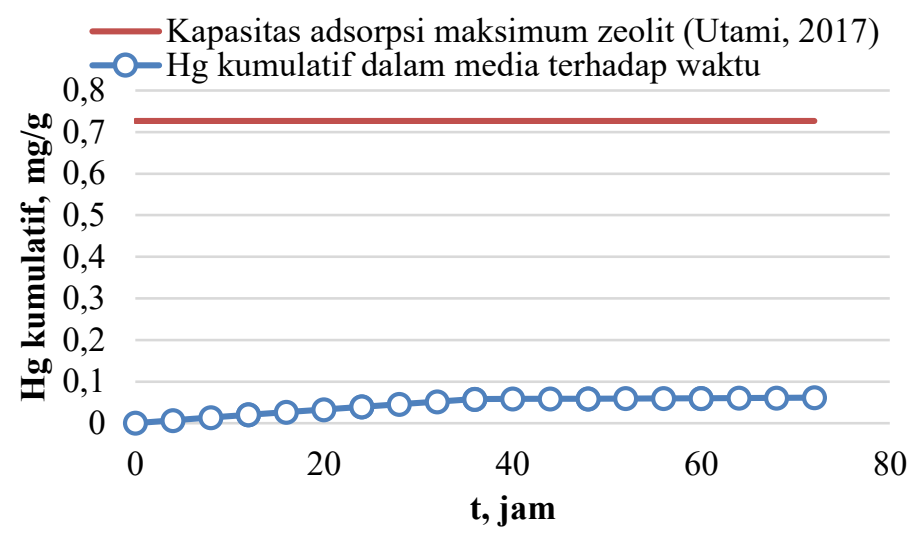

Gambar 8. Akumulasi merkuri pada SSF-CW terhadap waktu

Berdasarkan Gambar 8 diketahui bahwa zeolit akan mengalami kejenuhan ketika sudah melakukan 9 kali proses, hal ini terlihat dari tren grafik yang selama sekali proses (tahap I dan tahap II) mengakumulasi 0,08 $\mathrm{mg} / \mathrm{g}$. Kemampuan penjerapan merkuri oleh media zeolit dapat dihitung dari akumulasi Hg di SSF-CW sebesar $0,08 \mathrm{mg} / \mathrm{g}$ dikurangi akumulasi $\mathrm{Hg}$ pada tanaman $0,01713513 \mathrm{mg} / \mathrm{g}$, yaitu sekitar $0,06 \mathrm{mg} / \mathrm{g}$. Hal ini menunjukkan bahwa dari total akumulasi $\mathrm{Hg}$ selama proses adsorpsi-fitoremediasi dalam SSF-CW, terkonsentrasi sebesar $80 \%$ pada zeolit dan $20 \%$ pada tanaman. Konsentrasi Hg pada media zeolit yang cukup besar pada sistem SSF-CW ini menunjukkan dominasi akumulasi $\mathrm{Hg}$ pada media tanam. Hal ini diperkuat dengan pernyataan Zulhikman (2013), bahwa zeolit alam mempunyai struktur rangka yang mengandung ruang kosong yang ditempati oleh kation dan molekul air yang bebas. Kation aktif bergerak sebagai ion exchanger, prosesnya molekul bermuatan menyentuh suatu permukaan dengan muatan berlawanan, untuk kemudian saling berikatan secara kimiawi pada permukaan tersebut. Molekul-molekul dalam zeolit ini dapat bertukar posisi dengan molekul dalam air yang memiliki kecenderungan lebih kuat untuk mengikat dalam waktu tertentu. Zeolit alam juga memiliki pori dan luasan permukaan yang relatif besar sehingga mempunyai sifat adsorpsi yang tinggi dan menyumbang peran dalam menjerap ion merkuri lebih banyak.

\section{KESIMPULAN DAN SARAN}

Stabilitas sistem Sub-Surface Flow Constructed Wetland yang mengkombinasikan antara media tanam berupa zeolit dan tanaman melati air terlihat cukup baik untuk mendukung proses penurunan kadar logam $\mathrm{Hg}$ dalam air limbah dengan efisiensi penurunan sebesar 98,99\%. Hal ini dibuktikan dari tanaman melati air dapat beradaptasi dengan baik pada sistem yang dibuat dan mempunyai kemampuan akumulasi logam dengan nilai BCF sebesar 9,117. Sedangkan nilai TF yang didapatkan dari TF akar ke batang dan TF akar ke daun berturutturut adalah sebesar 0,281 dan 0,037 Adapun berdasarkan kemampuan media tanam, zeolit masih jauh dari kapasitas jenuhnya untuk menjerap merkuri. 
Jurnal Pengendalian Pencemaran Lingkungan (JPPL)

Vol.1 No.01 September 2019

\section{DAFTAR PUSTAKA}

Chaney, R.L. (1995). Potential Use of Metal Hyperaccumulators. Mining Environ Manag, 3, 9 - 11.

Dhir, B. (2013). Phytoremediation: Role of Aquatic Plants in Environmental Clean-Up. Springer New Delhi India

Keputusan Menteri Negara Lingkungan Hidup Nomor 202 tahun 2004 tentang Baku Mutu Air Limbah Bagi Usaha dan atau Kegiatan Pertambangan Bijih Emas dan atau Tembaga

Khiatudin, M. (2003). Melestarikan Sumber Daya Air dan Teknologi Rawa Buatan. Universitas Gadjah Mada Press Cetakan ke-2. Yogyakarta

Malik, R. Awaludin, Surakusumah, W., dan Koosbandia, S.H. (2016). Potensi Tanaman Air Sebagai Fitoakumulator Logam Kromium Dalam Limbah Cair Tekstil. Jurnal Riset Teknologi Pencegahan Pencemaran Industri (JRTPPI), 7(1)., 47-56.

Metcalf and Eddy. (2003). Wastewater Engineering Treatment and Reuse. Fourth Edition. Mc Graw Hill. California

Mudasir, M., Karelius, K., Aprilita, N.H., dan Wahyuni, E.T. (2016). Adsorption of mercury (II) on dithizoneimmobilized natural zeolite. Journal of Environmental Chemical Engineering, 4(2)., 1839-1849.

Peraturan Pemerintah Republik Indonesia Nomor 82 Tahun 2001 Tentang Pengelolaan Kualitas Air Dan Pengendalian Pencemaran Air

Sarafraz, S., Mohammad, T.A., Megat, J., Megat, M.N, dan Liaghat, A. (2009). Wastewater Treatment Using Horizontal Subsurface Flow Constructed Wetland. American Journal of Environmental Sciences, 5(1)., 99105.

UNEP. (2002). Global Environment Outlook 3, Past, present and future perspectives. London: Earthscan Publications Ltd.

U.S. Environmental Protection Agency. (2007). Treatment Technologies for Mercury in Soil, Waste, and Water. Washington DC : Office of Superfund Remediation and Technology Innovation.

Utami, F.N. (2017). Penghilangan Ion Merkuri (II) dari Hasil Buangan Limbah Industri Emas Menggunakan Metode Adsorpsi dengan Kombinasi Zeolite dan Asam Humat. Laporan Penelitian. Universitas Gadjah Mada.

Zulhikman, Meldy dkk. (2013). Efektivitas Zeolit dan Karbon Aktif Melalui Metode Penyaringan Up Flow dalam Menurunkan Kadar Merkuri Pada Air Limbah Pertambangan Emas Tradisional (Studi Kasus di Desa Jendi Kecamatan Selogiri Kabupaten Wonogiri Jawa Tengah). Jurnal Kesehatan Masyarakat Volume 2 Nomor 2 April 2013 